\title{
Dimension Stone: Exploration and Exploitation in parts of Lokoja, North-Central Nigeria
}

\section{EGESI, N; NWOSU, JI}

\author{
Department of Geology, University of Port Harcourt, Choba, Nigeria \\ *Corresponding Author Email: ndukauba.egesi@uniport.edu.ng
}

\begin{abstract}
The study area Lokoja is the home to the confluence between Rivers Niger and Benue. Dimension stone is cut or quarried stone in accordance with specific dimensions, generally more abundant and are used in greater quantities than ore minerals in pavement and several other constructional activities. The objective of the paper is to present prospects and a lead of rocks in Lokoja area for the production of dimension stone. The rocks in the area are being quarried as aggregates or mined as dimension stone and they met quality parameters of the rocks which includes, must be durable, easy to quarry, work, cut and polish. The particular stones selected depend upon the local weathering conditions which can be determined by amounts of industrial gases present and availability of the rocks locally. The rocks identified are marbles, granite gneisses, migmatites and biotite granites. The granites are being quarried for aggregates, marbles are powdered for cement production while migmatites and granite gneisses were mined for dimension stone.The results of Rock Strength (MPA), Rock Class Factor and Swell Factor are within acceptable standard limits except for migmatites with RS 36\%, RCF 7\% and SF $1.25 \%$, which is above the limit when compared with previous analysis of AAV 22.0\%, ACV23.3\%, AIV18\%and Absorption $0.54 \%$ in Boki area. The dimension stone were separated by more precise and delicate techniques, such as diamond wire saws, diamond belt saws, in the mine the cut dimension stone width are $1 \mathrm{~m}$, while many are rectangular in shape. They occur in the same geologic setting of the basement complex of Northcentral Nigeria. In the area investment has been at relatively low stage more investment will significantly increase production of the dimension stone for local usage, export and economic growth.
\end{abstract}

\section{DOI:https://dx.doi.org/10.4314/jasem.v24i3.4}

Copyright: Copyright (C) 2020 Egesi and Nwosu. This is an open access article distributed under the Creative Commons Attribution License (CCL), which permits unrestricted use, distribution, and reproduction in any medium, provided the original work is properly cited.

Dates: Received: 16 November 2019; Revised: 11 January 2020; Accepted: 22 February 2020

Keywords:Dimension stone, durable, available, maintenance, migmatite, Lokoja

The Lokoja area is the home to the confluence between River Niger and River Benue. The study area can be access through the River Niger and Lokoja Kporokpo road. All the rocks used for structural support, tiles for roofing, walls, veneer or different ornamental purposes is called building materials or building stone, while the rocks that has been cut and polished for finishing or predetermined uses in building construction and monuments is called dimension stone.

Dimension stone materials are not normally used in the building of a complete infrastructure, they are greatly valued for their good looks or aesthetic, appeal, durability, ease of maintenance and also cost of the stone.

The features for a good quality dimension stone are uniform texture and colour, freedom from flaws, suitability for polishing and carving and also resistance to weathering. Granite, charnockite, gneiss ,migmatite, marble, limestone, sandstone are the most popular (Egesi and Tse, 2011), (Egesi and Nwosu, 2018). The objective of the paper is to present prospects and a lead of rocks in Lokoja area for the production of dimension stone.

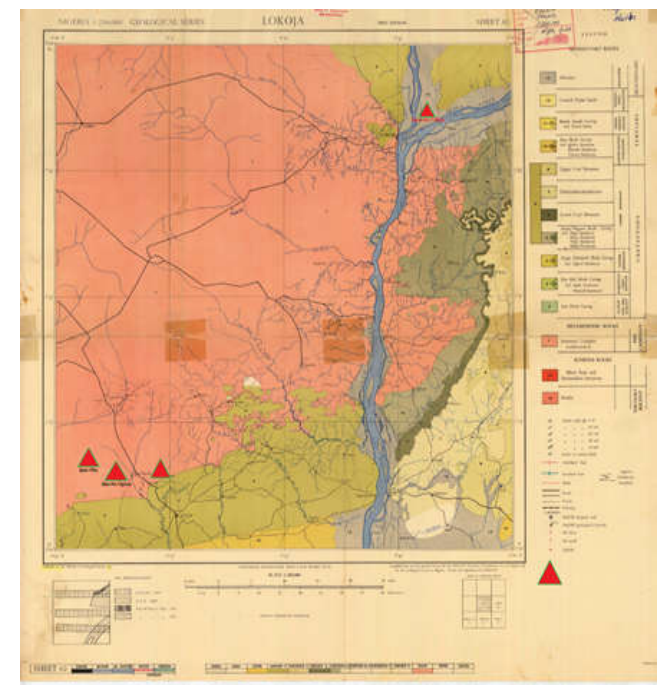

Fig 1. Geological map showing the confluence between River Niger and River Benue Lokoja area (modified after Hockey et al., 1986) 
The rocks in the area are being quarried as aggregates or mined as dimension stone and they met quality parameters of the rocks which includes, must be durable, easy to quarry, work, cut and polish.The Geological setting of the study area indicates it is within the southern portion the basement complex of Northcentral and within the confluence area between River Niger and River Benue. Over sixty-six percent of the Lokoja area is underlain by basement rocks which have been folded in several places. The remaining parts are covered by sedimentary rocks of Cretaceous and Recent Alluvium which lie unconformably over the basement complex rocks. The major rock units found in the area are Recent Alluvium, Upper Senonian to Lower Eocene sediments, Basic intrusives, Older (Pan African) granites, Charnockitic rocks, Migmatite-Gneiss complex and Metasediments. The Recent Alluvium covers considerable area within the confluence between River Niger and River Benue and extends southwards to Idah area and the Anambra River (Hockey et al., 1986). Figure1. is a Geological map of Lokoja showing the study area within the confluence area between River Niger and River Benue at the north-eastern part of the map.

\section{MATERIALS AND METHODS}

The methodology includes field and laboratory analysis. The exploration and production of rocks in the study area has been going on for different purposes. Reconnaissance and detailed survey of the area has been carried out by the Geological Survey of Nigeria (GSN) (Hockey et al., 1986) and also Faculty and students of Nigerian Universities. Presently, production of the dimension stone by Onshore Frontiers is being monitored by the Mines Department of the Federal Ministry of Mines and Steel Development state office in Lokoja. During our field survey in the area, marbles, granites, granite gneisses and migmatites were identified in the field. The marbles are crushed to powder for cement production while granites, granite gneisses and migmatites are for aggregates and dimension stone production. The rocks are well exposed with little or no overburden materials. In assessing the potential of a rock for use as dimension stone, the first requirement is petrographic analysis identifying the mineralogy, grain size, texture, fabric and weathering states which are determined by the geological processes that formed the rock. These processes are responsible for ways in which a rock may fail and help to increase the production of good quality dimension stone. The rock strength analysis for each sample collected from each quarryand petrographic analysis were made. Also average boulder sizes were measured in each quarry. Efforts were made to obtain some drilling and blasting parameters, rock strength testing information such as diameter of spacing and burden. Unfortunately, most of the companies who accepted to answer our questions restricted us from publishing some of the data given to us. Figure2, is a field photograph of biotite granite which has been blasted for the production of aggregates for pavement construction which can be use also in dimension stone production.

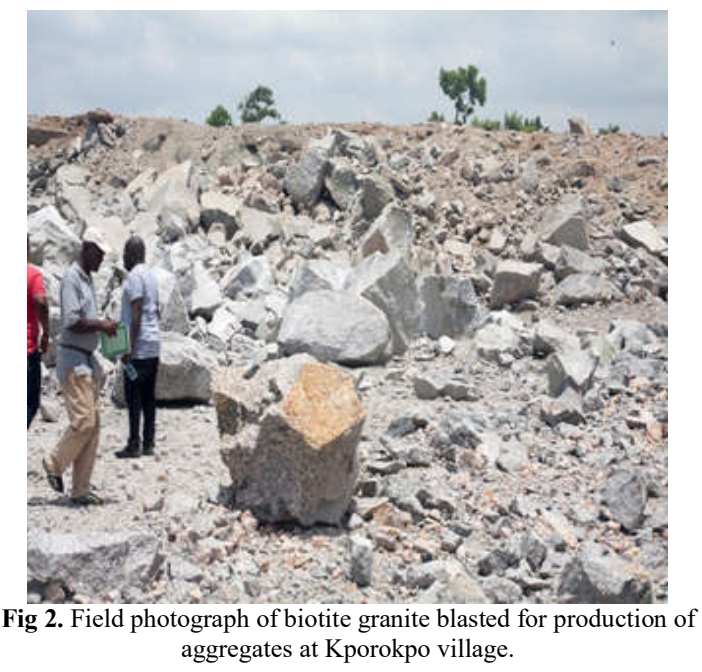

Dimension stone can be separated by more precise and delicate techniques, such as diamond wire saws, diamond belt saws, jet-piecers, or light and selective blasting with primacord, a weak explosive. Figures 3 and 4 below are the rocks and cutting edge machine which help the dimension stone exploration and production company trying to meet the huge demand in stone production and use, they are Chinese dimension stone mining equipment in operation at the Kporokpo site in Lokoja, Nigeria. The depth of the mine is about $7 \mathrm{~m}$.

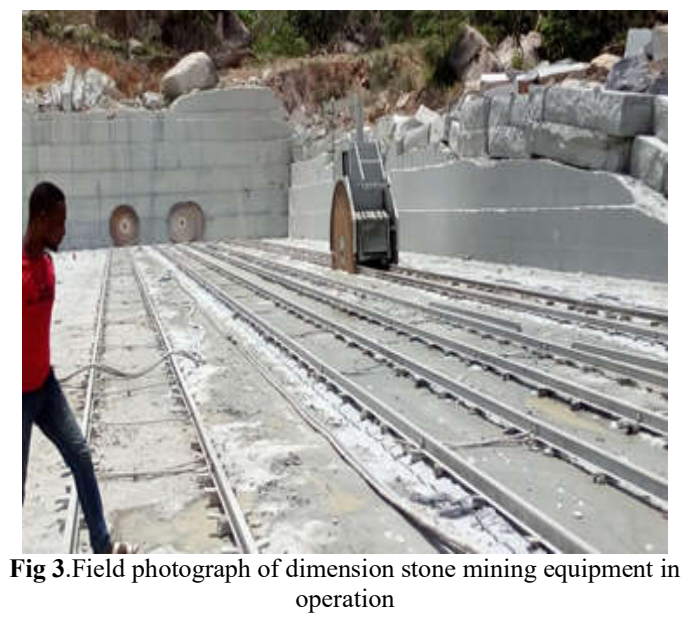


The procedure for dimension mining is quite different from aggregates quarrying. For aggregates the drilling of holes for blasting could be staggered, square, or rectangular, while lines which are square or rectangular are for dimension stone production. In the mine, some of the cut dimension stone are $1 \mathrm{~m}^{2}$, while many are rectangular in shape. The size of the rail shape design for the primary stone production is $1 \mathrm{~m}$ at the mine as shown Figures 3, 4 and 5.

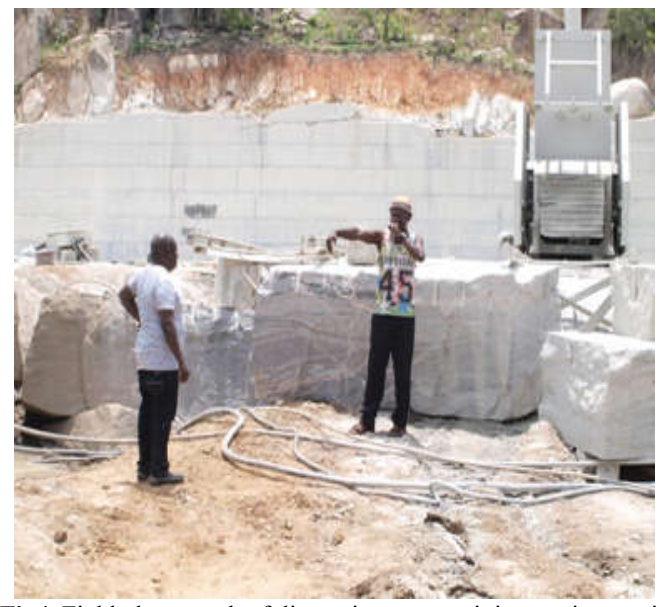

Fig4. Field photograph of dimension stone mining equipment in operation at Lokoja Nigeria

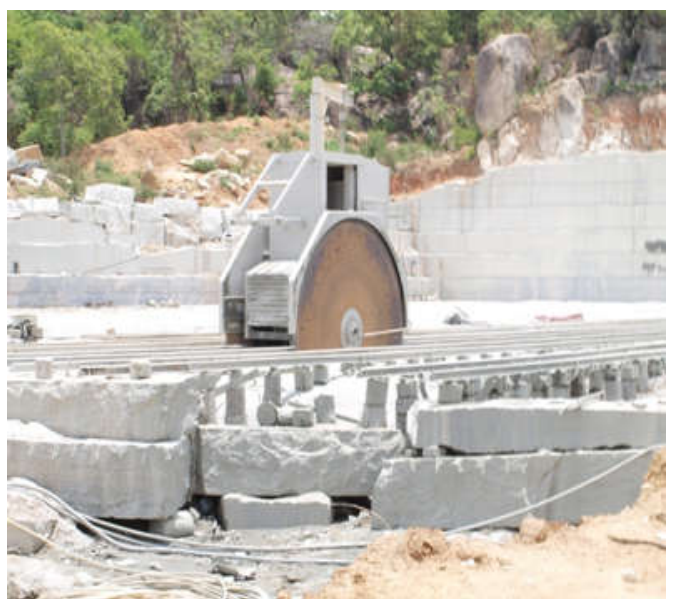

Fig 5.China dimension stone cutting equipment at Kporokpo village in Lokoja area, Nigeria

Figures 6 and 7 are the primary cut migmatites and granite gneisses before transportation to the processing plant through water or land. While the components of the dimension stone equipment at the mine was being explained by the operator in Figure 8 . The cut and polished dimension stone are shown in Figures 9 and 10 in floor tiles. The use of the materials for walls is increasing as it requires no painting but washing to clean dust after the dry season and green algal growth after the raining season.

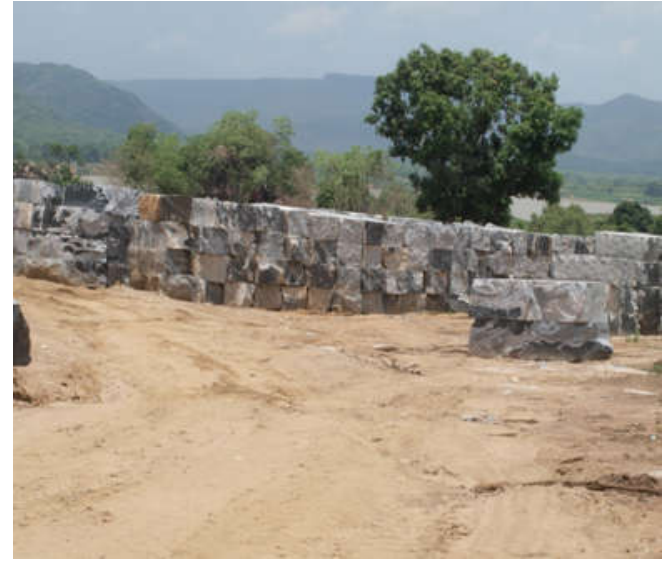

Fig 6.Field photograph of primary cut gneiss dimension stone migmatite parked before moving to secondary cutting and

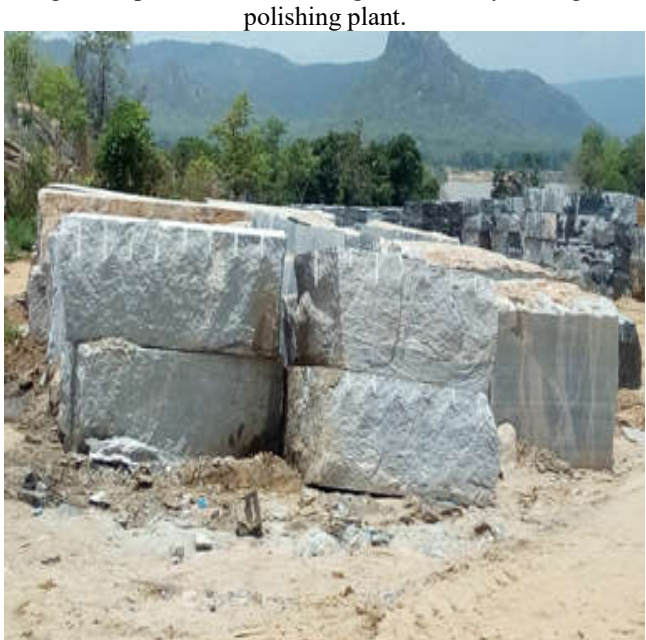

Fig 7. Field Photograph of granite gneisses while the migmatites and river is behind

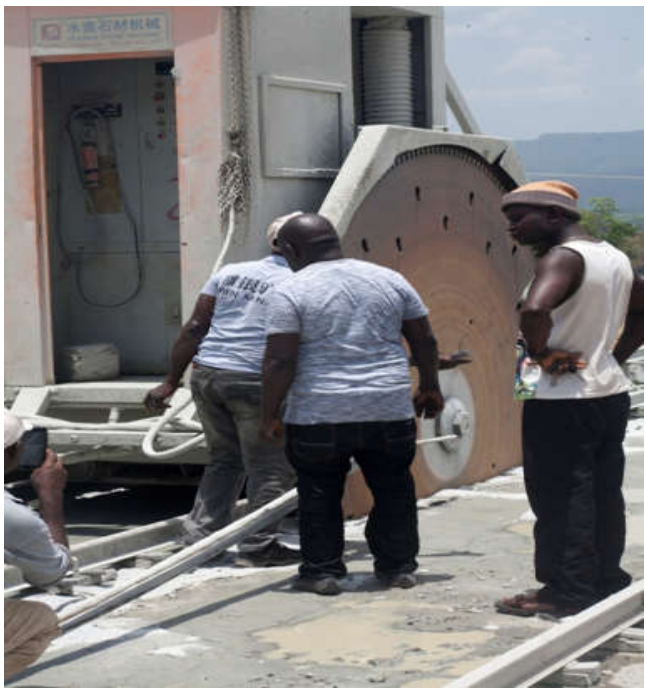

Fig 8.Field photograph of the machine operator explaining components of dimension stone cutting machine at Kporokpo site. 


\section{RESULTS AND DISCUSSION}

The results are shown on table 2 , while table 3 indicates the need for a trained geologist for sustainable dimension stone production. Figures 9 - 10 are cut and polished gneisses and migmatites which are similar to the rocks cut for dimension stone production in the study area, while Figures 11-12 are granites and charnockites which are present and in abundance in the study area but are yet to be invested in production of dimension stone.

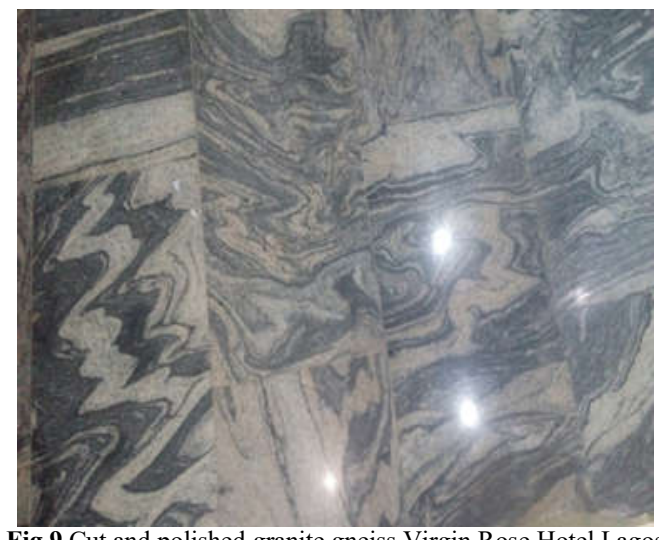

Fig 9.Cut and polished granite gneiss Virgin Rose Hotel Lagos

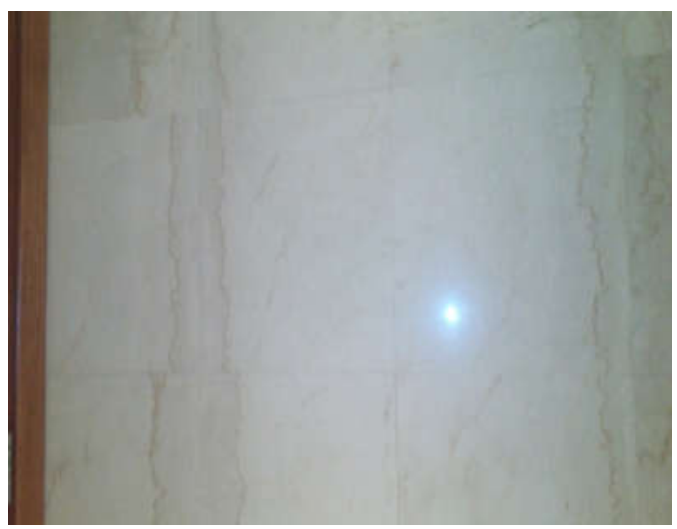

Fig 10.Cut and polished migmatite schist at Virgin Rose Hotel

$$
\text { Lagos }
$$

Table 1 is the result from some tested rocks in Boki area southeastern Nigeria showing Aggregate Abrasion Value (AAV), Aggregate Crushing Value (ACV), Aggregate Impart Value (AIV) and Absorption in percent, using British, American and German Standards, while table 2 is the present study in Lokoja area, Northcentral Nigeria. A comparison of the two tables shows that Aggregate Abrasion Value (AAV), Aggregate Crushing Value (ACV), Aggregate Impart Value (AIV), Absorption in percent, Rock Strength (MPA), Rock Class Factor and Swell Factor are within acceptable limits except for migmatites which is above the standard limit. The specific roles of a geologist in dimension exploration and production is indicated on Table 3 (Egesi and Tse, 2011). In the production of dimension stone, a trained geologist will be required to apply appropriate sequence from exploration, evaluation, exploitation, production and research and development to ensure sustainability.

Table 1. Test Results for some rock samples in Boki Southeastern Nigeria (Egesi and Ukaegbu, 2013)

\begin{tabular}{lllll}
\hline Rock Samples & $\begin{array}{c}\text { AAV } \\
\text { in \% }\end{array}$ & $\begin{array}{l}\text { ACV } \\
\text { in \% }\end{array}$ & $\begin{array}{l}\text { AIV } \\
\text { in \% }\end{array}$ & $\begin{array}{l}\text { Absorption } \\
\text { in \% }\end{array}$ \\
\hline Biotite-Granite & 22.0 & 23.2 & 18.5 & 0.54 \\
Granite-Gneiss & 27.0 & 26.1 & 22.8 & 0.73 \\
Charnockite & 22.5 & 24.0 & 19.5 & 0.62 \\
Acceptable & $<30$ & $<30$ & $<35$ & $<10$
\end{tabular}

Standard (BS

AASHTO, ASTM,

DIN)

Table 2: Average rock strength for each quarry as established by Total Quality Nigeria Ltd Effurun Delta State Nigeria (Nwosu et al., 2019)

\begin{tabular}{lllll}
\hline QUARRY & TYPE OF ROCR & $\begin{array}{l}\text { ROCK } \\
\text { STRENGHT(MPA) }\end{array}$ & FACTOR. & FACTOR \\
\hline QUARRY 1 & GRANTIE & 23 & 5 & 1.2 \\
QUARRY 2 & MARBLE & 16 & 4 & 1.12 \\
QUARRY 3 & GRANTE & 24 & 5 & 1.2 \\
QUARRY 4 & MARBLE & 20 & 4 & 1.12 \\
QUARRY 5 & MGMATITS & 36 & 7 & 1.25 \\
QUARRY 6 & MARBLE & 16 & 4 & 1.12 \\
QUARRY 7 & GRANTE GNEISS & 26 & 5 & 1.2 \\
QUARRY 8 & MARBLE & 16 & 4 & 1.12 \\
\hline
\end{tabular}

Table 3.The role of the geologist in dimension stone exploration, evaluation and development and production (Egesi and Tse, 2011).

\begin{tabular}{ll}
\hline Roles & Details \\
\hline Exploration & $\begin{array}{l}\text { Find rock of the quality required } \\
\text { in the market and its availability. }\end{array}$ \\
& $\begin{array}{l}\text { Assessment of the rock to } \\
\text { establish its suitability for the } \\
\text { market. }\end{array}$ \\
Mine or Quarry planning & $\begin{array}{l}\text { Consideration of the shape and } \\
\text { position of rock in relation to the } \\
\text { environment, methods and ease of } \\
\text { extraction, advise on }\end{array}$ \\
& $\begin{array}{l}\text { qualityvariations like physical, } \\
\text { chemical or mechanical strength. }\end{array}$ \\
& $\begin{array}{l}\text { Assessment of quality after } \\
\text { processing. Methods and effects } \\
\text { of wastedisposal for reject or bi- } \\
\text { product materials. Advise on }\end{array}$ \\
suitable systemsbearing in mind \\
nature of rock. \\
Advise on short and long term \\
variations in quality of rock \\
material. \\
Advise customers on nature of \\
rock impurities and their likely \\
consequences during use, supply \\
and quality changes for each rock. \\
Investigate and examine potential \\
for new products, improvement of \\
manufacturing techniques in \\
which the rock is used and \\
principles and procedures for \\
quality improvement in silicate \\
and oxides systems.
\end{tabular}


The study area has received exploration surveys by the Geological Survey of Nigeria (GSN) from workers like (Hockey et al., 1986). The details of the geology of the area can be obtain from the Geological Survey series Bulletin 39. There is an abundance of rocks like charnockite, marble, quartzite, granite, sandstone, gneiss and slate which can be prospects in the area and also comparable with rocks in places like India, Italy, Spain, Israel and Brazil.

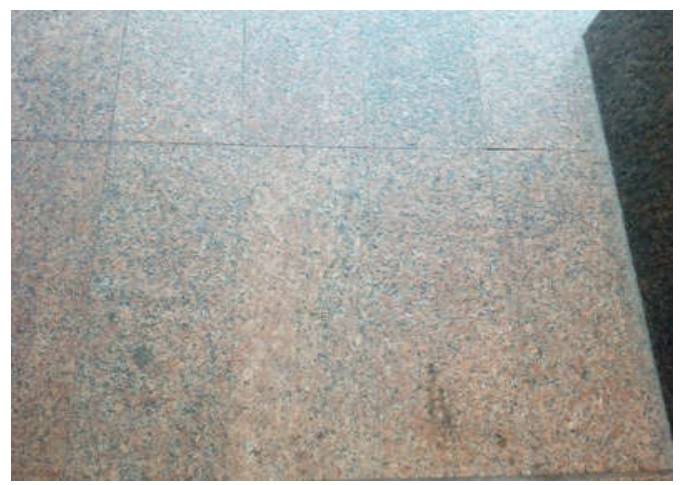

Fig11.Cut and polished biotite granite at Eko Hotels Lagos

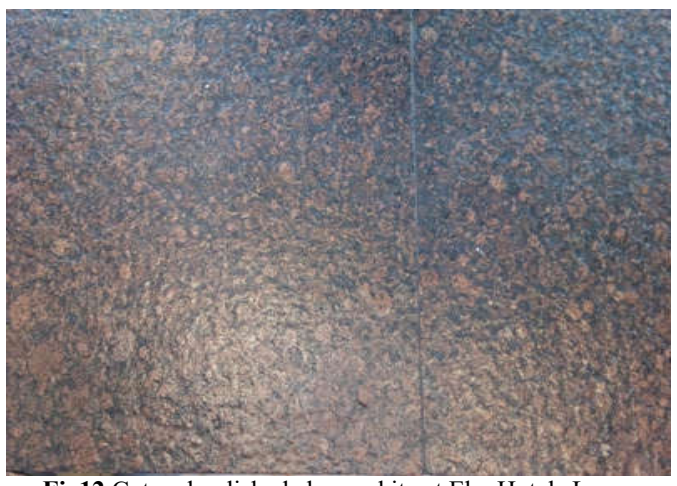

Fig12.Cut and polished charnockite at Eko Hotels Lagos

These countries are among the largest producers and leading exporters of dimension stone in the world. They are obtain and used in iconic buildings all over the world, Indian stone meets the most exacting world standards like durability, appeal and ease of maintenance. The Lokoja area has marbles, granites, migmatites and granite gneisses that are good and will meet world standard. The results of the rock strength analysis from tables 1 and 2 are comparable for granites and granites gneisses but not for migmatites, which is 36\% Egesi and Tse (2012), (Egesi and Ukaegbu, 2013) in theBoki area southeastern Nigeria and (Nwosu, et al. 2019) and Nwosu, et al. (in press) in the Lokoja area Northcentral Nigeria. There is need for investment in dimension stone production to reduce the present dependence on large scale importation and also create employment opportunities in the states that have comparative advantage on availability of the rocks suitable for dimension stone production.

Conclusion: The Lokoja area has prospects and abundant rocks for dimension stone and aggregates production. However, investment in stone production has been relatively low, very few companies are involved presently. To invest in dimension stone, there is need to have geologists with adequate knowledge of the rock properties, petrography, rock strength and use in accordance with known standards BS, ASTM, AASHTO and German DIN. These will assist in diversification of the economy from the non- oil sector and create job opportunities.

\section{REFERENCES}

Egesi, N; Tse, AC (2011). Dimension Stone: Exploration, Evaluation, Exploitation in southwest parts of Oban Massif, southeastern Nigeria. J. Geol. Min.Res. 3 (4):115-122

Egesi, N; Tse, AC (2012). Engineering-Geological Evaluation of Rock materials from Bansara, Bamenda massif Southeastern Nigeria, as aggregates for Pavement Construction. Geosci.2012, 2(5): 107-111.

Egesi, N; Ukaegbu, VU (2013). Dimension Stone Exploration and Development in Boki Area Southeastern Nigeria. J. Appl. Sci. Environ. Manage. 17 (3): 343-354.

Egesi, N; Nwosu, JI (2018). Crushed rock and dimension stone: exploration, evaluation and Exploitation in parts of Igarra Area, southwest Nigeria. Inter. J. Sci.7 (01).

Nwosu, JI; Egesi, N; Onwualu-John, JN (2019). Provision of Optimum blasting parametersof mineral deposits in Auchi-Igarra mineral district and Okene-Lokoja mineral district, Nigeria. Research Team Geology Department, University of Port Harcourt in collaboration with Federal Ministry of Mines and Steel Development, Abuja. p.58

Nwosu, JI; Egesi, N; Onwualu-John, JN (in press). Effects of bench height over-estimation on fragmentation.

Hockey, RD; Sacchi, R; Muotoh, EOG; Graaff, WPFH (1986). The Geology of Lokoja-Auchi Area. Geol. Survey Nig. Bull. 39: 71. 